\title{
Molecular characterization of Pseudomonas from Agaricus bisporus caps reveal novel blotch pathogens in Western Europe
}

\author{
Tanvi Taparia ${ }^{1,2^{*}}$ D, Marjon Krijger ${ }^{1}$, Edward Haynes ${ }^{3}$, John G. Elphinstone ${ }^{3}$, Ralph Noble ${ }^{4}$ and Jan van der Wolf ${ }^{*}$
}

\begin{abstract}
Background: Bacterial blotch is a group of economically important diseases affecting the cultivation of common button mushroom, Agaricus bisporus. Despite being studied for more than a century, the identity and nomenclature of blotch-causing Pseudomonas species is still unclear. This study aims to molecularly characterize the phylogenetic and phenotypic diversity of blotch pathogens in Western Europe.

Methods: In this study, blotched mushrooms were sampled from farms across the Netherlands, United Kingdom and Belgium. Bacteria were isolated from symptomatic cap tissue and tested in pathogenicity assays on fresh caps and in pots. Whole genome sequences of pathogenic and non-pathogenic isolates were used to establish phylogeny via multi-locus sequence alignment (MLSA), average nucleotide identity (ANI) and in-silico DNA:DNA hybridization $(\mathrm{DDH})$ analyses.

Results: The known pathogens "Pseudomonas gingeri", P. tolaasii, "P. reactans" and P. costantinii were recovered from blotched mushroom caps. Seven novel pathogens were also identified, namely, P. yamanorum, P. edaphica, P. salomonii and strains that clustered with Pseudomonas sp. NCO2 in one genomic species, and three nonpseudomonads, i.e. Serratia liquefaciens, S. proteamaculans and a Pantoea sp. Insights on the pathogenicity and symptom severity of these blotch pathogens were also generated.

Conclusion: A detailed overview of genetic and regional diversity and the virulence of blotch pathogens in Western Europe, was obtained via the phylogenetic and phenotypic analyses. This information has implications in the study of symptomatic disease expression, development of diagnostic tools and design of localized strategies for disease management.
\end{abstract}

Keywords: Multilocus sequence alignment, Average nucleotide identity, In-silico DNA DNA hybridization, "Pseudomonas gingeri", Pseudomonas sp. NCO2, Serratia spp., Pseudomonas salomonii, Pseudomonas yamanorum, Pseudomonas edaphica, Bacterial blotch, Pathogenicity, Pot test, Cap test

\footnotetext{
*Correspondence: tanvi.taparia@wur.nl; jan.vanderwolf@wur.nl

${ }^{1}$ Biointeractions and Plant Health, Wageningen University and Research, Wageningen, Netherlands

Full list of author information is available at the end of the article
}

(C) The Author(s). 2020 Open Access This article is licensed under a Creative Commons Attribution 4.0 International License, which permits use, sharing, adaptation, distribution and reproduction in any medium or format, as long as you give appropriate credit to the original author(s) and the source, provide a link to the Creative Commons licence, and indicate if changes were made. The images or other third party material in this article are included in the article's Creative Commons licence, unless indicated otherwise in a credit line to the material. If material is not included in the article's Creative Commons licence and your intended use is not permitted by statutory regulation or exceeds the permitted use, you will need to obtain permission directly from the copyright holder. To view a copy of this licence, visit http://creativecommons.org/licenses/by/4.0/ The Creative Commons Public Domain Dedication waiver (http://creativecommons.org/publicdomain/zero/1.0/) applies to the data made available in this article, unless otherwise stated in a credit line to the data. 


\section{Background}

Commercial button mushroom cultivation relies heavily on the dynamic interactions between Agaricus bisporus and the casing soil microflora [1]. The transformation of vegetative mycelium into a fruiting body is initiated by beneficial microbes in the casing soil [2-4]. However, the casing soil also introduces pathogenic microbes into mushroom farms, including blotch causing Pseudomonas species [5-7]. The humid and mesophilic conditions required for mushroom production are highly conducive to the enrichment and spread of such pathogens. Reliable identification and early detection is thus essential to avoid disease outbreaks.

The genus Pseudomonas is one of the most complex genera of Gram negative bacteria due to its large size of 114 species [8]. They form a major proportion ( 40\%) of the total culturable bacteria obtained from casing soil in mushroom farms [9]. While some of these are essential for stimulating the pinning of button mushrooms (e.g. P. putida) $[1,10]$, others are detrimental to crop health (e.g. P. tolaasii) $[11,12]$.

Bacterial blotch is a group of diseases that result in discolouration and disfiguration of mushroom caps in $A$. bisporus, due to fungal production of phenols and tyrosinases [13]. This reduces the total marketable crop due to compromised aesthetic value, lowers the shelf-life post-harvest, and lessens the overall yields due to pin death. These aspects of bacterial blotch jointly lead to severe economic losses [14-16]. Various Pseudomonas species are the main causative agents of blotch diseases on mushroom caps [7].

$P$. tolaasii causes small sunken dark brown spots or lesions on the mushroom cap that are referred to as "brown blotch" $[11,12]$. "P. reactans" is known to cause varying discoloration from dark to light, accompanied by a surface depression [17] and " $P$. gingeri" produces ginger coloured discolorations that are more spread out on the cap surface, called "ginger blotch" [18]. Both of these species have not been formally described. $P$. agarici is the causative agent of "drippy gill" on A. bisporus and "yellow blotch" on oyster mushrooms (Pleurotus spp.), where it leads to relatively pale discolorations [19]. Global reports also indicate the role of other Pseudomonas, such as $P$. costantinii, $P$. fluorescens and $P$. marginalis in bacterial blotch diseases, with large phenotypic variation within and across species [20].

Blotch pathogens can be considered as endemic to the casing soil, an artificially prepared growth media composed of peat and lime, that is added on top of the compost $[5,21]$. They have been found on healthy crops at similar densities to that of diseased crops [9]. It has thus been suggested that not just the pathogen density, but the composition of Pseudomonas species in the casing soil, especially the relative abundance of beneficial and disease-causing species, can be an important indicator for disease outbreaks [9]. A deeper understanding of the beneficials and pathogens within the genus is hence necessary.

Bacterial blotch has been studied for over a century $[22,23]$, despite which the identity and nomenclature of blotch-causing Pseudomonas is still unclear. Recent molecular investigations clarify the taxonomy of some blotch pathogens [24-27]. However, knowledge on the identity, diversity and pathogenicity of mushroomassociated Pseudomonas species at the regional scale is still lacking. This information is instrumental for the development of localized strategies for diagnostics, disease control and breeding of varieties.

In this study, we isolated Pseudomonas from blotched mushrooms on farms in the Netherlands, United Kingdom and Belgium. We performed whole genome sequence analyses of pathogenic isolates to develop a deeper understanding of the genetic diversity among the pathogens in Western Europe. Some non-pathogenic isolates were also included in the study. The molecular characterization of these isolates provides insights into the phylogenetic relationships between beneficial and blotch-causing Pseudomonas species commonly associated with the button mushroom, A. bisporus.

\section{Methods}

\section{Bacterial isolations}

Blotched mushrooms were sampled from commercial farms in the Netherlands, United Kingdom and Belgium for isolation of blotch-causing Pseudomonas species. Biopsies from symptomatic tissue of the cap surface $\left(2 \mathrm{~cm}^{2}\right.$ area) were made in sterilized Ringer's solution [28], and homogenized in a polyethylene bag (Bioreba, Switzerland). The extract from each biopsy was dilution plated on King's B medium [29]. After incubation at $25^{\circ} \mathrm{C}$ for $48 \mathrm{~h}$, single colonies were picked and re-plated. In total, 161 single colonies of suspected Pseudomonas spp., that were fluorescent under UV light $(365 \mathrm{~nm})$, were plated to pure cultures by re-streaking on King's B medium. One isolation was also made from a healthy mushroom that did not display visible blotch symptoms. A list of bacterial isolates is presented as Additional file 1.

\section{Pathogenicity assays}

All isolates were tested in an in vitro assay to check their pathogenicity. Bacterial strains were cultured in King's B medium [29] at $25^{\circ} \mathrm{C}$ for $24 \mathrm{~h}$, and tested in the bioassay. Similarly sized cap surfaces $(4-5 \mathrm{~cm}$ in diameter) of healthy mushrooms were placed on damp filter paper and inoculated with $20 \mu \mathrm{l}$ of aqueous bacterial suspension of $10^{6}$ colony-forming units ( $\mathrm{cfu}$ ) per $\mathrm{ml}$ from the isolate, and tested in replicates of three. The mushrooms were incubated under high humidity conditions for $72 \mathrm{~h}$ 
at $20^{\circ} \mathrm{C}$. The development of blotch symptoms on the cap surface was observed visually and photographed. The isolates were scored, between 0 and 3, with the ascending numbers referring to non-pathogenic, mild, moderate, and severe symptoms for bacterial blotch [25]. Negative controls consisted of uninoculated mushroom caps and sterile water inoculated mushroom caps.

A selection of isolates were re-tested in pot assays. Mushrooms were grown in plastic pots $(230 \mathrm{~mm}$ diameter $\times 220 \mathrm{~mm}$ depth) containing $4 \mathrm{~kg}$ of Phase III compost, spawn-run with the most commonly cultivated mushroom strain, Sylvan A15. The pots were cased with 1.3 L of casing soil (moist mixture of peat and sugar beet lime). The pots were watered with sterile water and incubated at $25^{\circ} \mathrm{C}$ for 7 days. The room was then ventilated and the air temperature reduced to $18{ }^{\circ} \mathrm{C}$ and the relative humidity was maintained at 91-93\%, until the end of the cultivation cycle. After 5 days, the casing soil in each pot was inoculated with $50 \mathrm{ml}$ of aqueous bacterial suspension of $10^{7} \mathrm{cfu} / \mathrm{ml}$. The development of blotch symptoms on the mushrooms was recorded over two flushes and scored as above. The type of blotch symptoms (brown, ginger or others) was recorded and photographed. Negative controls consisted of casing soil inoculated with sterile water.

\section{DNA extraction and sequencing}

For NL and BE isolates, $250 \mathrm{mg}$ of bacterial slime was picked from a pure culture on an agar plate, and used as starting material. Total DNA was extracted using Wizard Magnetic DNA Purification System for Food (Promega, United States) according to the manufacturer's protocol, including the DNase-free RNAse treatment. Library construction was performed using Illumina Truseq Nano (Illumina, United States) with $1 \mu \mathrm{g}$ of bacterial DNA. $125 \mathrm{bp}$ paired-end sequencing of the DNA libraries was done using HiSeq2500 (Illumina, United States).

For UK isolates, a single colony was picked from each agar plate and extracted using the Qiagen DNeasy Blood and tissue kit following the manufacturer's protocol. The DNA was quantified fluorometrically using a Quant-iT PicoGreen dsDNA Assay Kit (Thermo Fisher Scientific, United States) on the Infinite M200 PRO (Tecon, Switzerland) and then stored at $-80^{\circ} \mathrm{C}$ for downstream processing. Library construction was performed using Illumina Nextera XT library preparation kit (Illumina, United States) with $0.8 \mathrm{ng}$ of bacterial DNA. Sequencing of the DNA libraries was performed on the MiSeq (Illumina, United States) using the V3 Reagent Kit, generating $300 \mathrm{bp}$ paired-end sequences.

The combined dataset included 68 newly generated genome sequences from bacteria isolated from symptomatic cap tissue, 30 sequences of mushroom-associated
Pseudomonas species from a previous sampling [25] and 15 sequences of related strains obtained from NCBI (https://www.ncbi.nlm.nih.gov/). Quality control was performed on the raw reads prior to read mapping using CLC Genomics Workbench (QIAGEN, Germany). Adapter sequences were removed from the raw reads. Bases with Phred quality scores less than 20 based on a modified-Mott algorithm were trimmed. Raw reads greater than $1000 \mathrm{bp}$ and less than $45 \mathrm{bp}$ were discarded. Reads were trimmed to a final length of $125 \mathrm{bp}$ (NL and $\mathrm{BE}$ isolates) and $300 \mathrm{bp}$ (UK isolates). Trimmed reads were mapped to the reference genomes without masking. Non-specific matches were randomly mapped.

\section{Determination of prokaryotic taxonomy}

Multi-Locus Sequence Alignment (MLSA) with trimmed coding sequences of eleven barcoding genes from 13 reference strains were used to establish phylogeny between the isolates [30]. Housekeeping genes were chosen as phylogenetic molecular markers based on several criteria. The genes had a single copy number, they code universally for ubiquitous proteins with housekeeping functions, are likely recalcitrant to the effects of horizontal gene transfer, are long enough (>900 bp) to contain sufficient information, and can predict whole-genome relationships [31]. Trimmed reads were mapped to the concatenated sequences of individual barcoding genes from multiple reference strains, using Map Reads to Reference 1.6 with a similarity and length fraction of 0.9 (CLC Genomics Workbench 11.0.2). Consensus DNA sequences were extracted from the mapping, and used for making phylogenetic trees with maximum likelihood and maximum parsimony methods [32]. Graphics from phylogenetic trees were made in RStudio [33] using package ggtree [34].

Genome assemblies were performed on the trimmed reads using De Novo Assembly 1.4 with a minimum contig length of $200 \mathrm{bp}$ (CLC Genomics Workbench 11.0.2). Legacy BLAST [35] based Average Nucleotide Identity (ANI) analysis [36] was performed on the contig sequences from the assembled genomes using pyani 0.2.9 [37]. Similarity value of $95 \%$ was used as cut-off threshold for identification of a unique taxonomic group. The similarity values were used for phylogenetic analyses and to create graphics in RStudio [33]. To clarify the taxonomy of isolates that did not cluster together with any of the reference strains in the ANI or the MLSA, a digital DNA: DNA hybridization [38] was performed using the Genome-genome distance calculator (GGDC) [39]. A threshold of $70 \%$ for digital DNA:DNA hybridization and $1 \%$ for difference in percentage guanine-cytosine content were used for determination of species and subspecies boundaries via the Type (Strain) Genome Server [40]. Phylogenetic trees were constructed from the alignment 
of the whole-genomes and their corresponding $16 \mathrm{~S}$ rRNA sequences, using a GreedyWithTrimming algorithm on FastME 2.0 [41].

\section{Results}

\section{Pathogenicity of isolates}

102 bacterial isolates were tested for their ability to cause bacterial blotch symptoms on fresh mushroom caps (Fig. 1). 6 out of the 17 strains that belonged to international culture collections could cause blotch symptoms. Out of the 85 bacterial isolates recovered from blotched mushroom tissue, 55 isolates caused mild to severe symptoms in the pathogenicity cap test. From this panel, the pathogenicity of 30 bacterial isolates and strains were also validated in the pot test, by inoculation of the pathogen in the casing soil (Fig. 2). The pot test and cap test gave similar results (Additional file 1). The pathogenicity of the isolates is further described in this text with reference to bacterial blotch only.

\section{Whole genome sequences}

In total, whole genome sequences from 113 bacteria were analysed. The consortium of sequenced bacteria contained 85 isolates from symptomatic mushroom tissue and 28 reference strains from international culture collections at LMG (Laboratory of Microbiology, Belgium), ATCC (American Type Culture Collection, United States) and NCPPB (National Collection of Plant Pathogenic Bacteria, United Kingdom). The total number of reads per isolate, averaged across the dataset, were $16,075,321$ indicating good sequencing depth, with mean Phred score of 38 which suggests high sequence quality and mean GC content of $63 \%$. Additional file 1 describes the sequence identifiers and their metadata.

\section{Multi-locus sequence analysis}

Eleven taxon-specific sequences that are stable with regard to rapid genetic mutations were selected as barcoding genes from known literature reports [8, 25, 42], namely,
atpD, fusA, glnS, groeL, gyrB, ileS, recA, recN, rpoB, rpoD and $u v r C$ (Table 1). Concatenated sequences of the barcoding genes from 13 reference strains of well-known mushroom-associated Pseudomonas species (Table 2) were used for MLSA, such that the variability within the barcoding genes predicts the overall whole genome relatedness [30]. Two of these strains from the P. fluorescens group were added to the reference list based on preliminary data exploration. P. yamanorum is a psychrotolerant soil bacterium from the $P$. fluorescens group [43], that contains a paralog of the tolaasin gene fragment [44]. Pseudomonas sp. NCO2 is a recently isolated soil bacterium, which is closely related to $P$. yamanorum.

The largest clusters in the phylogenetic tree are comprised of "P. gingeri", Pseudomonas sp. NCO2 "P. reactans" and $P$. tolaasii, in decreasing order of size. " $P$. gingeri" and "P. reactans" isolates formed multiple clusters within the species (Fig. 3). A few isolates also mapped to barcoding genes from $P$. putida, $P$. agarici, $P$. veronii, $P$. costantinii and $P$. yamanorum. With the exception of "P. gingeri", non-pathogenic isolates were also found in species clusters that contained pathogenic isolates.

None of the isolates mapped to reference strains of $P$. poae, $P$. protegens, $P$. fluorescens or $P$. syringae. 15 out of 113 isolates mapped non-specifically, with relatively low percentage identity, to multiple reference strains indicating the presence of other Pseudomonas species. 5 isolates did not map to any of the references and could potentially be non-pseudomonads. Within species clusters of the phylogenetic tree, the individual isolates had low numbers of substitutions per sequence site, indicating short evolutionary distances within species (Fig. 3).

\section{Average nucleotide identity}

Average nucleotide identity analysis recognized 32 unique bacterial phylotypes associated with the cap tissue of blotched button mushrooms in Western Europe (Fig. 4). These are phylogenetically distinct whole

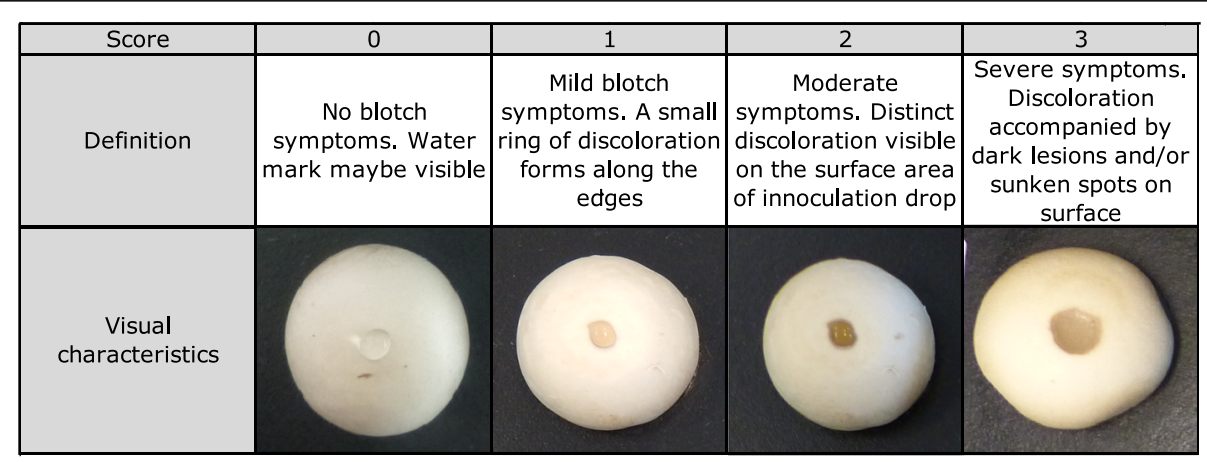

Fig. 1 In-vitro pathogenicity assays to quantify the virulence of an isolate when inoculated on fresh mushroom caps. It describes the visual characteristics used to score the blotch symptoms as none, mild, moderate and severe in a pathogenicity assay 


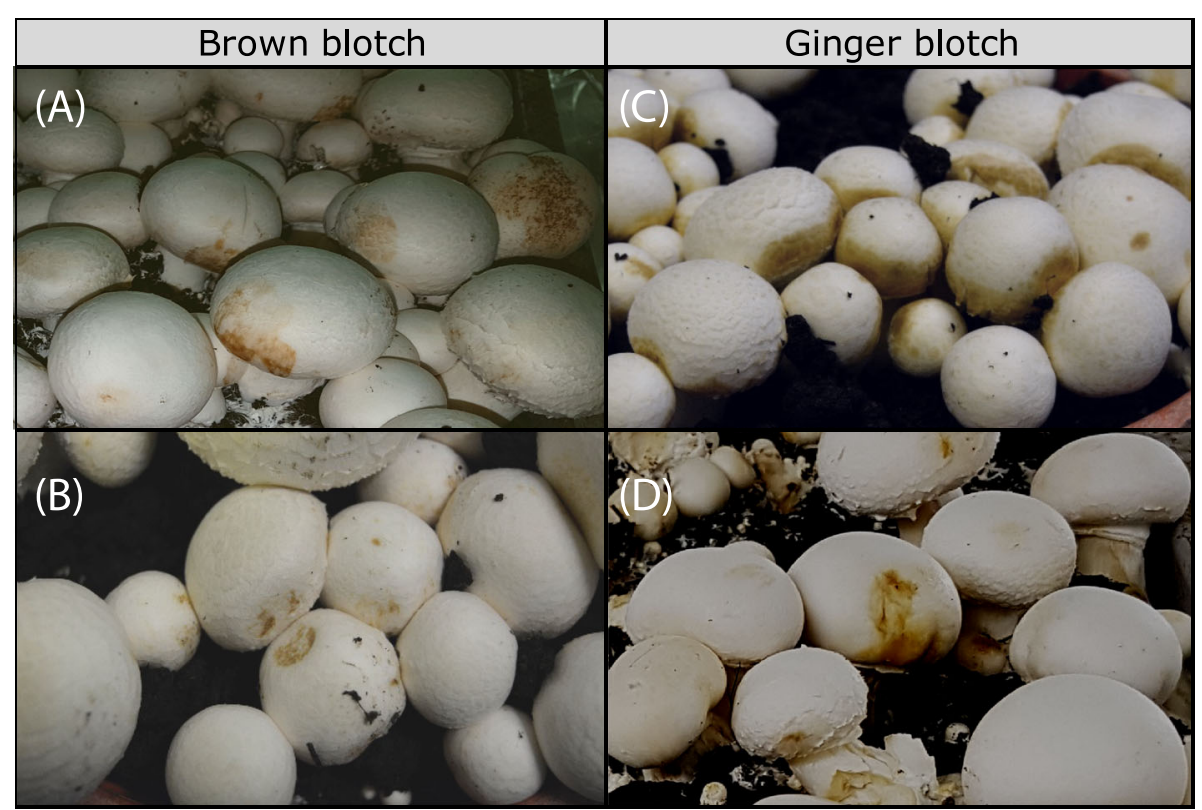

Fig. 2 Pathogenicity bioassays in pots to confirm the virulence of isolates when inoculated in the casing soil. Brown blotch symptoms were caused by (a) P. salomonii (IPO3765) and (b) P. costantinii (LMG 22119 $)$ and ginger blotch symptoms were caused by "P. gingeri" isolates (c) P8018 and (d) IPO3777, in independent pathogenicity bioassays in pots

genome sequences differing at species level, based on $\mathrm{a}<95 \%$ similarity cut-off for delineation. Similar to the MLSA, the largest numbers of blotch pathogens were identified as close relatives of Pseudomonas sp. NCO2 or "P. gingeri", although pathogenic isolates of $P$. tolaasii, $P$. costantinii, "P. reactans" and $P$. yamanorum were also discovered. Isolates that were unable to cause blotch were primarily identified as " $P$. reactans", $P$. agarici, $P$. veronii and strains belonging to the same species as Pseudomonas sp. NC02. Within phylotypes, isolates did

Table 1 List of individual barcoding genes used for predicting whole-genome relatedness in MLSA

\begin{tabular}{lll}
\hline $\begin{array}{l}\text { Barcoding } \\
\text { gene }\end{array}$ & Description or product & Length variation \\
\hline atpD & ATP synthase subunit beta & $0471-1380 \mathrm{bp}$ \\
fusA & Elongation factor G & $2106-2148 \mathrm{bp}$ \\
glnS & Glutamine--tRNA ligase & $1482-1701 \mathrm{bp}$ \\
groeL & Chaperonin 1 & $1620-1650 \mathrm{bp}$ \\
gyrB & DNA gyrase subunit B & $2379-2424 \mathrm{bp}$ \\
iles & Isoleucine--tRNA ligase & $2106-2832 \mathrm{bp}$ \\
recA & DNA repair protein A & $0612-1065 \mathrm{bp}$ \\
recN & DNA repair protein N & $1672-1674 \mathrm{bp}$ \\
rpoB & DNA-directed RNA polymerase & $4074-4081 \mathrm{bp}$ \\
rpoD & (subunit B) & \\
& RNA polymerase sigma factor & $0519-1851 \mathrm{bp}$ \\
uvrC & (sigma-70) & \\
& UvrABC system excinuclease & $1824-1839 \mathrm{bp}$ \\
\hline
\end{tabular}

not cluster according to geographic region, year of outbreak or pathogenicity scores. Twelve unidentified phylotypes consisted of isolates with varying levels of symptom severity on fresh mushroom caps and did not contain any reference or type strains.

\section{In-silico DNA:DNA hybridization}

Five non-pseudomonad isolates were identified from insilico DDH of the whole genome sequences (Table 3). Two isolates that cause moderate blotch on fresh caps,

Table 2 List of genomes used for extracting the reference sequences of the barcoding genes for MLSA

\begin{tabular}{ll}
\hline Reference genomes & Accession (Assembly) \\
\hline P. poae LMG $21465^{\top}$ & GCA_001439785.1 \\
P. protegens CHAO & GCA_000397205.1 \\
P. veronii LMG $17761^{\top}$ & GCA_001439695.1 \\
P. costantinii LMG $22119^{\top}$ & GCA_001870435.1 \\
P. putida BIRD 1 & GCA_000183645.1 \\
"P. reactans" LMG $5329^{\top}$ & GCA_000411675.1 \\
P. agarici LMG $2112^{\top}$ & GCA_900109755.1 \\
P. tolaasii LMG $2342^{\top}$ & GCA_002813445.1 \\
"P. gingeri" LMG $5327^{\top}$ & GCA_002895165.1 \\
P. fluorescens LMG $1794^{\top}$ & GCA_900215245.1 \\
P. syringae DC3000 & GCA_000007805.1 \\
P. yamanorum LMG $27247^{\top}$ & GCA_900105735.1 \\
Pseudomonas sp. NC02 & GCA_002874965.1 \\
\hline
\end{tabular}




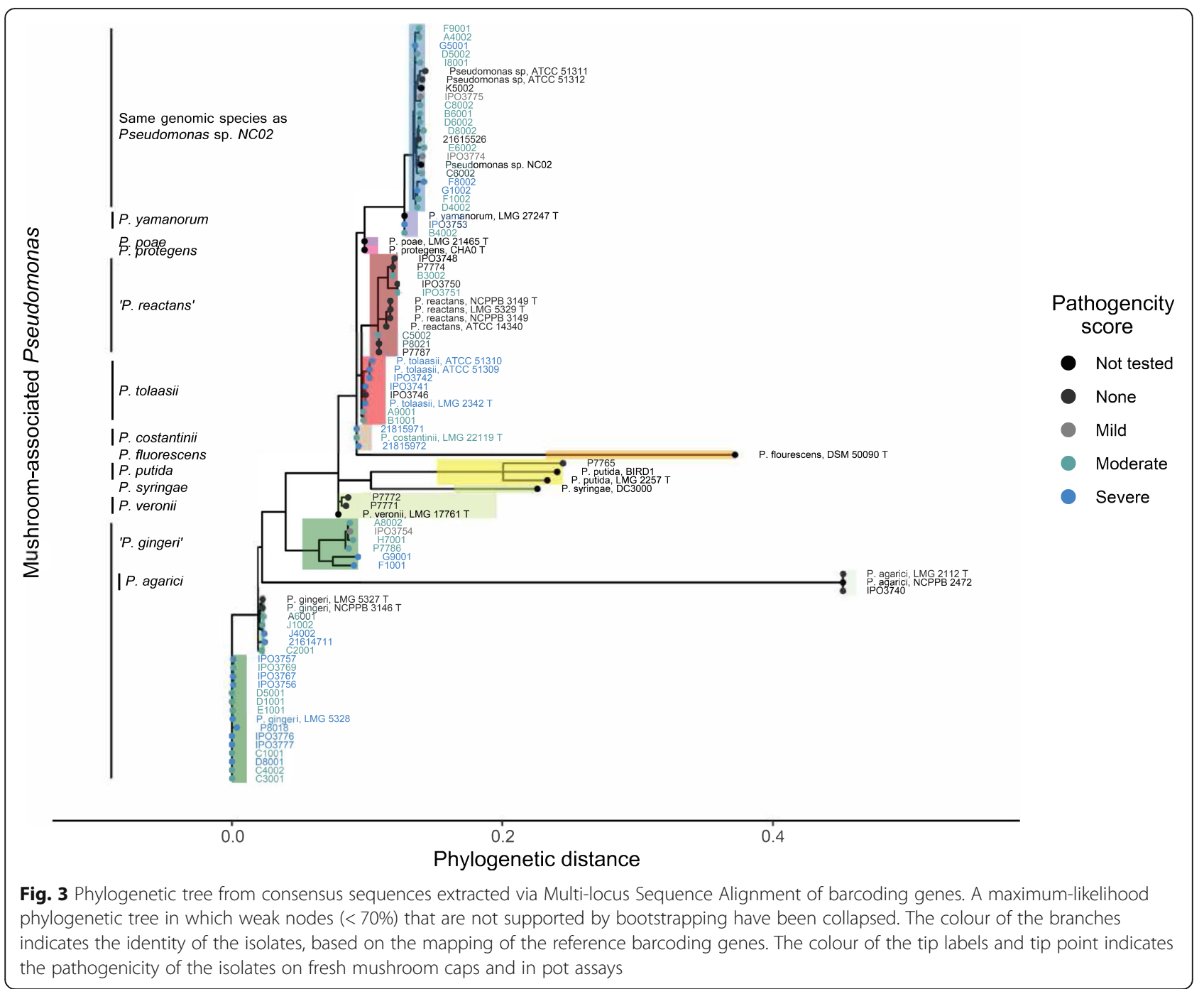

C2002 (phylotype 15) and C7002 (phylotype 17) were identified as Serratia liquefaciens and Serratia proteamaculans respectively (Fig. 5). Non-pathogenic isolate P7753 (phylotype 30) was closely related to Brevundimonas bullata. Non-pathogenic isolate P7760 (phylotype 31) was closely related to Cedecea neteri. Moderate blotch-causing isolate B9002 (phylotype 13) was related to reference genomes of multiple Pantoea species.

Among the Pseudomonas, three isolates that cause blotch on fresh caps (phylotype 12) belonged to P. edaphica and severe blotch-causing isolate IPO3765 (phylotype 25) was identified as P. salomonii (Fig. 6). Several Pseudomonas spp. did not hybridize sufficiently (> 70\%) with any of the type strains or share a similar \%GC content $(<1 \%)$. Seven of these isolates (phylotypes 4 and 26) were closely related to $P$. yamanorum LMG $27247^{\mathrm{T}}$. Isolates P7548 (phylotype 9) and B6002 (phylotype 11), clustered together as the same genomic species, and were closely related to P. fluorescens DSM $50090^{\mathrm{T}}$ (>
$60 \%$ dDDH). Isolate D2002 (phylotype 21) was also closely related to $P$. fluorescens. Isolate B3002 (phylotype 16) did not map sufficiently with the type strain of " $P$. reactans", in contrast to the MLSA and ANI results.

\section{Taxonomic corrections}

The taxonomy of several reference strains from culture collections have been corrected based on the combined results from MLSA, ANI and $\mathrm{ADDH}$ analyses. ATCC 51312, ATCC 51311, LMG 2343 were formerly identified as $P$. tolaasii, but they share less than $95 \%$ genome similarity with $P$. tolaasii genome cluster (phylotype 6). They also do not map to barcoding genes of $P$. tolaasii LMG $2342^{\mathrm{T}}$. Non-pathogenic strains ATCC 51312 and ATCC 51311 were instead identified close relatives of Pseudomonas sp. NCO2 (phylotype 2) in the MLSA and ANI, and LMG 2343 (phylotype 12) was identified as $P$. edaphica in the dDDH. Non-pathogenic isolates P7774, P7753 and P7760 were formerly described as P. veronii, 


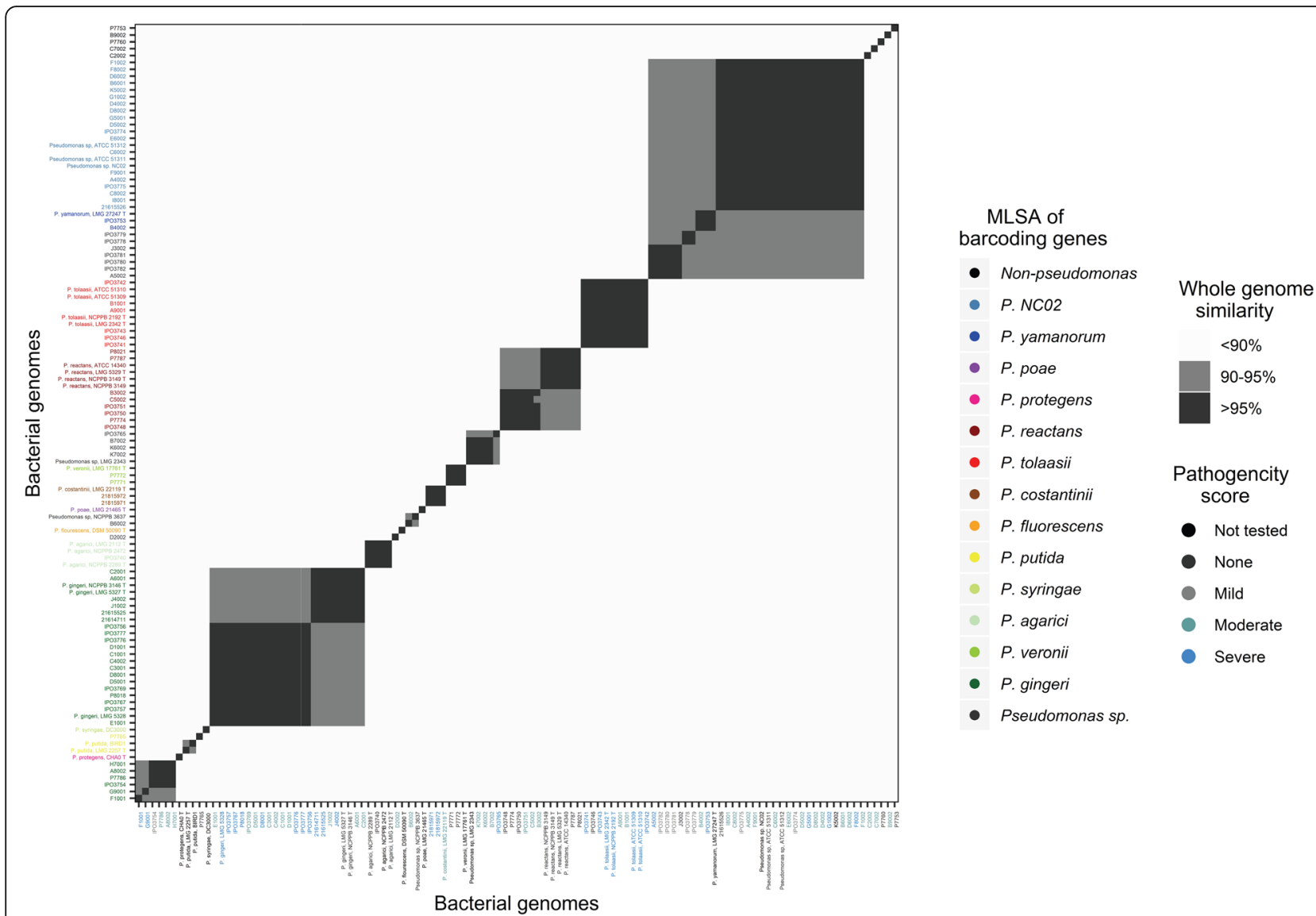

Fig. 4 Heatmap from whole-genome similarity values obtained in the Average Nucleotide Identity analysis. Colours of the heatmap indicate the pairwise genome-genome similarity. The labels on the $y$-axis are coloured according to the identity assumed from the MLSA analyses; the labels on the $\mathrm{x}$-axis are coloured according to the pathogenicity of the isolates on fresh mushroom caps, and in select cases also pot tests

$P$. syringae and $P$. agarici, respectively, in internal culture collections. Based on ANI and dDDH results from this study they were re-identified as "P. reactans" (phylotype 16), close relative of Brevundimonas bullata (phylotype 30) and close relative of Cedecea neteri (phylotype 31) respectively.

\section{Known blotch pathogens}

All strains of P. tolaasii (phylotype 6) isolated from blotch outbreaks in the Netherlands were found to cause moderate or severe brown blotch symptoms, with the exception of IPO 3746. They also map to barcoding genes of $P$. tolaasii LMG $2342^{\mathrm{T}}$ in the MLSA. Two pathogenic isolates from the United Kingdom, 21,815, 971 and 21,815,972 (phylotype 3) that cause severe blotch and pitting in both cap and pot tests, clustered together with the blotch-causing reference strain of $P$. costantinii, LMG $22119^{\mathrm{T}}$ in the MLSA and ANI. Three isolates from the "P. reactans" clusters, B3002, C5002, IPO 3751 (phylotypes 9 and 16), were also pathogenic. All 26 isolates of "P. gingeri" obtained from blotch outbreaks in the Netherlands, United Kingdom and Belgium were able to cause blotch, with varying symptom severity in the pathogenicity tests performed. All of them mapped to barcoding genes of " $P$. gingeri" LMG $5327^{\mathrm{T}}$. They form 3 MSLA clusters, but 5 distinct ANI clusters (phylotypes 1, 5, 14, 22 and 24), indicating that multiple closely-related species can cause ginger blotch.

\section{New blotch pathogens}

Several isolates presented in this study are reported as blotch-pathogens for the first time. 19 isolates (phylotype 2) with varying severity of blotch symptoms were identified as belonging to the same species as Pseudomonas sp. NC02. Two blotch-causing isolates (phylotype 10) from the Netherlands were identified as $P$. yamanorum. They were also closely related to the Pseudomonas sp. NCO2 isolates. Three pathogenic isolates (phylotype 12) from Dutch blotch outbreaks were identified as $P$. edaphica. A severely pathogenic isolate (IPO3765) from Netherlands was recognized as $P$. salomonii.

Four ANI clusters (phylotypes 4, 9, 21 and 26) contained pathogenic Pseudomonas isolates without a 
Table 3 In-silico DNA:DNA hybridization of unidentified isolates

\begin{tabular}{|c|c|c|c|c|c|}
\hline Query isolate & Phylo-type (ANI) & Reference strain & dDDH value (\%) & Confidence intervals (\%) & Difference in GC (\%) content \\
\hline \multicolumn{6}{|c|}{ Non-Pseudomonas } \\
\hline B9002 & 13 & Pantoea rodasii LMG $26273^{\top}$ & 40.5 & $37.5-43.5$ & 0.9 \\
\hline C2002 & 15 & Serratia liquefaciens LMG $7884^{\top}$ & 96.5 & $95.0-97.6$ & 0.14 \\
\hline C7002 & 17 & Serratia proteamaculans NCPPB $245^{\top}$ & 93.4 & $91.1-95.1$ & 0.01 \\
\hline P7753 & 30 & Brevundimonas bullata LMG $17157^{\top}$ & 72 & $68.5-75.2$ & 0.22 \\
\hline P7760 & 31 & Cedecea neteri LMG $7864^{\top}$ & 63 & $59.7-66.2$ & 0.55 \\
\hline \multicolumn{6}{|c|}{ Pseudomonas species } \\
\hline A5002 & 4 & P. yamanorum LMG $27247^{\top}$ & 69.2 & $65.8-72.5$ & 0.63 \\
\hline IPO3780 & 4 & P. yamanorum LMG $27247^{\top}$ & 70.3 & $66.8-73.5$ & 0.73 \\
\hline IPO3781 & 4 & P. yamanorum LMG $27247^{\top}$ & 68.2 & $64.8-71.4$ & 0.59 \\
\hline IPO3782 & 4 & P. yamanorum LMG $27247^{\top}$ & 70.9 & $67.4-74.1$ & 0.76 \\
\hline$J 3002$ & 4 & P. yamanorum LMG $27247^{\top}$ & 69.1 & $65.7-72.4$ & 0.67 \\
\hline B6002 & 9 & Isolate P7548 (phylotype 11) & 80.9 & $77.5-83.9$ & 0.24 \\
\hline P7548 & 11 & P. fluorescens DSM $50090^{\top}$ & 57.3 & $54.1-60.5$ & 0.61 \\
\hline B7002 & 12 & P. edaphica LMG $30152^{\top}$ & 88.2 & $85.2-90.6$ & 0.03 \\
\hline IPO3747 & 12 & P. edaphica LMG $30152^{\top}$ & 89.9 & $87.1-92.1$ & 0.1 \\
\hline K6002 & 12 & P. edaphica LMG $30152^{\top}$ & 89.8 & $87.0-92.0$ & 0.12 \\
\hline K7002 & 12 & P. edaphica LMG $30152^{\top}$ & 89.9 & $87.1-92.1$ & 0.1 \\
\hline B3002 & 16 & P. reactans $L M G 5329^{\top}$ & 44.4 & $41.4-47.4$ & 2.94 \\
\hline D2002 & 21 & P. fluorescens DSM $50090^{\top}$ & 69.4 & $65.4-73.0$ & 0.15 \\
\hline IPO3765 & 25 & P. salomonii LMG $22120^{\top}$ & 87.9 & $84.4-90.7$ & 0.31 \\
\hline IPO3778 & 26 & P. yamanorum LMG $27247^{\top}$ & 64.8 & $61.5-68.1$ & 0.59 \\
\hline IPO3779 & 26 & P. yamanorum LMG $27247^{\top}$ & 64.8 & $61.5-68.0$ & 0.6 \\
\hline
\end{tabular}

Only the highest dDDH values from comparing each query strain with multiple reference strains have been reported. Values in bold indicate that the query belongs to the same species as the reference strain, as the confidence intervals meet the $70 \%$ threshold for DDH and $1 \%$ difference in $\% G C$ content. Values that are not highlighted, lie on the border or below the thresholds, and indicate the reference that the query isolate is most closely related to

reference or type strain. Phylotype 4 contained only one severe blotch-causing isolate, A5002. Phylotypes 9 and 21 contained only a single isolate each, both of which (B6002 and D2002) cause brown blotch symptoms. Phylotype 26 contained two unidentified isolates, IPO 3778 and IPO 3779 that cause mild-blotch on fresh caps.

\section{Unidentified Pseudomonas species}

10 isolates demonstrating a range of blotch severity, from non-pathogenic to severe symptoms, remained unidentified. They mapped to barcoding genes from multiple reference strains in the MLSA, formed 7 distinct clusters (phylotypes 4, 9, 11, 21, 26, 30 and 31) in the ANI analysis (Fig. 4), and were closely but insufficiently $(<70 \%)$ related to any other species in the dDDH (Table 3 ). Their contigs mapped in-specifically to multiple reference strains, when compared via BLAST against the NCBI database. Contamination of these isolates during laboratory work was ruled out by confirming the presence of single-copies of the barcoding genes, and low genome duplication in the range of $1.50-2.84 \%$
(Additional file 2). These could potentially be new species that have yet to be discovered.

\section{Non-pathogenic Pseudomonas}

Five non-pathogenic isolates, P7787, P8021, P774, IPO 3748 and IPO3750, mapped to barcoding genes from " $P$. reactans" LMG $5329^{\mathrm{T}}$ in the MLSA, but were split over phylotype 8 and 16 in the ANI analysis. All isolates from phylotype 19 did not cause blotch and mapped to barcoding genes of $P$. agarici LMG $2112^{\mathrm{T}}$, better known as the causative agent of drippy gill. Fluorescent Pseudomonas spp. such as P. putida (phylotype 23, 29, 30), P. veronii (phylotype 27) and P. poae (phylotype 20) that are usually considered as beneficial organisms, were also confirmed to be non-pathogenic.

\section{Discussion}

Genetic diversity of blotch-causing Pseudomonas

The established phylogeny of bacterial isolates associated to symptomatic cap tissue is largely consistent between the MLSA, ANI and dDDH analyses. This substantiates the conclusions made about the identity of blotch 


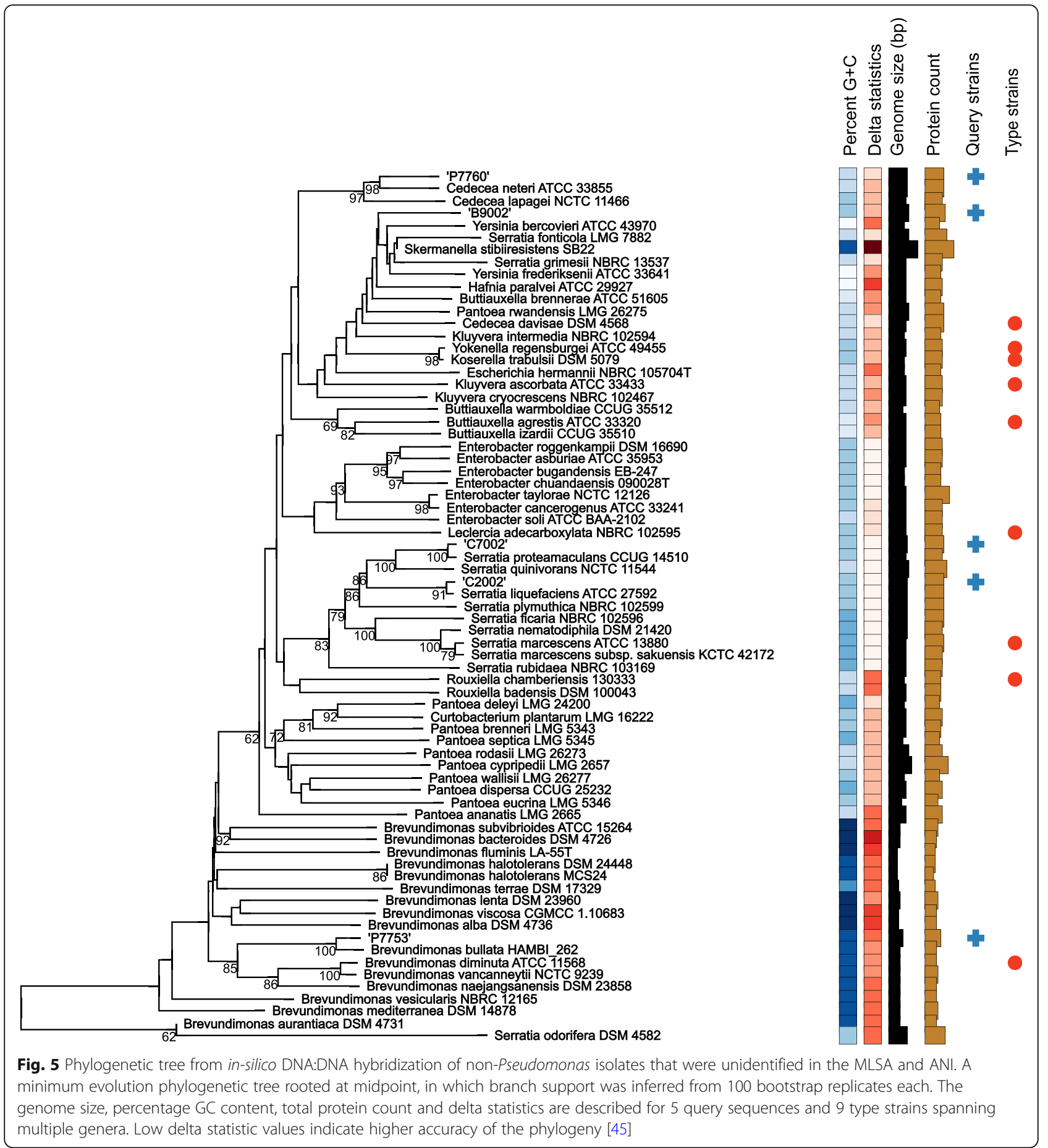

pathogens, and the related taxonomic corrections. "P. gingeri", $P$. tolaasii, "P. reactans" and P. costantinii are known causative agents of bacterial blotch $[4,11,17$, 24]. In addition, several novel blotch pathogens were identified in these analyses, namely $P$. yamanorum, $P$. edaphica, $P$. salomoni and strains clustering together with Pseudomonas sp. NCO2, as the same genomic species.
P. yamanorum is a recently described psychrotolerant member of the $P$. fluorescens group that was found in Argentinian soil under cold and humid climatic conditions [43]. In a recent study, the tolaasin gene fragment of a few brown blotch-causing isolates in Turkey were also found to share homology with that of $P$. yamanorum [44]. Pseudomonas sp. NCO2 is a recently isolated soil bacterium about which not much is known [46]. $P$. 


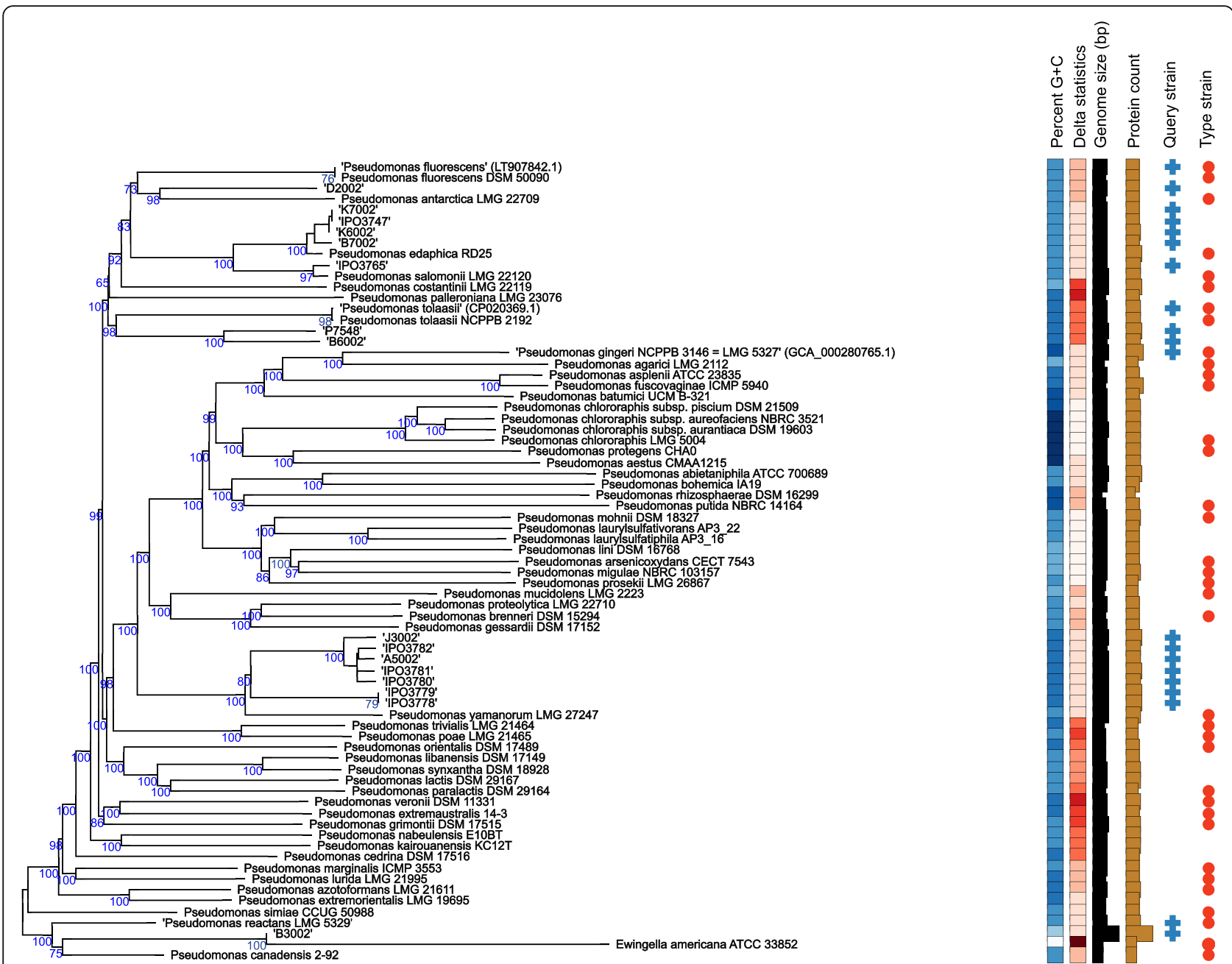

Fig. 6 Phylogenetic tree from in-silico DNA:DNA hybridization of Pseudomonas isolates that were unidentified in the MLSA and ANI. A minimum evolution phylogenetic tree rooted at midpoint, in which branch support was inferred from 100 bootstrap replicates each. The genome size, percentage GC content, total protein count and delta statistics are described alongside the phylogenetic tree for 21 query sequences and 45 type strains from the genus Pseudomonas

edaphica is another newly identified fluorescent Pseudomonas that was isolated from rhizosphere soil, and is closely related to P. brenneri [47]. P. salomonii was first characterized as a pathogen of 'Café au lait' disease on garlic [48], and was later also recovered from ready-toeat vegetables [49]. This is the first report of the blotchcausing ability of this pathogen on mushrooms. Its pathogenicity in the cap test was also verified by pot tests.

"P. gingeri" and "P. reactans" are both invalidly named species known to cause bacterial blotch $[17,18,50]$. In this study, all isolates previously classified as "P. gingeri" and " $P$. reactans" map to barcoding genes of their respective reference strain, although they form multiple distinct clusters in the MLSA as observed from the phylogenetic tree (Fig. 3). They also split into multiple phylotypes in the ANI analysis instead of clustering together (Fig. 4). Delineation of these phylotypes on a genome level (<95\% similarity) despite mapping to barcoding references from the same species, perhaps indicates the existence of a species complex with multiple taxonomically-related species, as opposed to other blotch pathogens which cluster as single phylotypes.

On the basis of genomic and phylogenetic analyses such as MLSA, ANI and dDDH, this study also reports four blotch-causing Pseudomonas spp. (phylotypes 4, 9, 21 and 26) which do not belong to any of the existing species within the genus Pseudomonas. These are as yet unidentified, and could potentially be new species. The taxonomic assignment of these novel blotch-causing phylotypes as new species requires a polyphasic approach involving additional phenotypic and chemotaxonomic data such as fatty acid methyl esters, polar lipids and respiratory quinones, etc. [51]. 


\section{Pathogenicity and phylogeny}

Koch's postulates were evaluated to identify causative agents of bacterial blotch [52]. Bacteria were isolated from symptomatic mushroom tissue and successfully grown to pure culture. In every case, blotch symptoms could be reproduced when isolates were inoculated on mushroom caps. The 4th postulate of Koch, i.e. reisolation of pathogen from the experimental host and its identification as originally inoculated pathogen, was not fulfilled. The mushroom cap surfaces also harbour endemic Pseudomonas spp. that are closely related to the isolates, and have similar characteristics and colony morphology [53, 54]. Due to lack of diagnostic methods, the inoculated isolates cannot be easily differentiated from the endemic microflora. However, the disease developement can be attributed to the inoculated pathogens with certainty, due to the presence of multiple mock-inoculated negative controls which did not develop any blotch symptoms.

$24,8,39$ and 28 isolates were confirmed to cause nonpathogenic, mild, moderate and severe blotch symptoms respectively, on fresh mushroom caps in an in-vitro pathogenicity test. Bacterial isolates did not cluster together according to their pathogenicity scores in the MLSA or ANI analysis. Often blotch-causing and nonpathogenic isolates were part of the same phylotype or branch (Figs. 3 and 4). This elaborates the need for a pan-genomic analysis to identify the pathogenicity determinants of bacterial blotch diseases. Fluorescent Pseudomonas share a rather small core genome of 1344-protein coding genes [55]. The size and diversity of the pangenome is thus determined by secondary metabolites biosynthesis clusters that can be strain specific and responsible for pathogenicity [56]. Pan-genomic elements shared exclusively by pathogenic isolates can be ideal targets for the further development of DNA-based diagnostic tools.

\section{Regional diversity of blotch-causing Pseudomonas}

Within species, bacterial isolates did not cluster together according to their geographic region or year of outbreak. The two Belgian isolates (IPO 3781 and IPO 3782), both caused mild ginger blotch and clustered together with those of the Netherlands. Two Dutch isolates of " $P$. gingeri" (IPO 3757 and IPO 3756) that caused severe ginger blotch, clustered differently from each other in phylotypes 14 and 24 respectively. The phylogenetic distribution of the common pathogens independently from their region of outbreak indicates that Western Europe shares a well-mixed pathogen pool.

However, a few potentially region-specific blotch pathogens were also recovered in this study. P. yamanorum, $P$. edaphica and $P$. salomonii isolates have so far only been found in the Netherlands. P. costantinii isolates in this study, 21,815,971 and 21,815,972, which cause brown blotch and pitting, have been found only in the United Kingdom, although other blotch-causing $P$. costantinii have been reported in Finland too [57]. It is also important to consider that very few isolates from these species were found in this study. This regional exclusivity could also be an artefact of low sampling due to the low presence of these species.

\section{Blotch causing non-pseudomonads}

Two Serratia species, S. liquefaciens, (C2002, phylotype 15) and S. proteamaculans, (C7002, phylotype 17) were recovered from blotched caps in this study. Serratia species are present in casing soil, compost, and on mushroom caps [53, 58-60]. Serratia liquefaciens is a known agent of yellow blotch on the caps of A. bisporus [61]. They cause browning of the $A$. bisporus sporophore [62] by secreting chitinolytic enzymes and chitin-binding proteins [63]. They also produce a surfactant, serwettin, which enables the bacterium to colonise fresh areas of the mushroom cap, as tolaasin does [64, 65]. P. fluorescens also uses a similar mechanisms to spread on broccoli heads [66].

A moderately pathogenic Pantoea isolate (B9002, phylotype 13) was also identified in this study. Pantoea species have been previously isolated from caps of $A$. bisporus [60], and are frequently recovered from soil and water environments too $[67,68]$. This gram negative bacterium is an agent of soft rot disease on the stipes and pileus of Pleurotus eryngii [69], although it has not yet been reported to be a pathogen of A. bisporus. Pantoea species from waste mushroom beds are also used for production of plant auxin, indole-acetic acid, for phosphate solubilization [70].

A non-pathogenic Cedecea isolate (P7760, phylotype 31 ), closely related to $C$. neteri, was also found on a blotched mushroom cap. Cedecea were one of the most common genera recovered from blotched tissue of $A$. brazilensis [71] and is often present on A. bisporus also [72]. Although Cedecea neteri is an agent of soft rot in Pholiota nameko [73] and yellow sticky disease in Flammulina velutipes [74], only Cedecea davisae strains have been reported to cause blotch in A. bisporus [61].

\section{Beneficial bacteria on symptomatic cap tissue}

Non-pathogenic and potentially beneficial bacteria were also recovered from cap tissue of blotched mushrooms. P. putida (P7771, P7772, phylotype 27) and P. veronii (P7765, phylotype 32) isolates were confirmed to be non-pathogenic on fresh mushroom caps. P. putida, $P$. poae and $P$. veronii are known to stimulate primordia formation of $A$. bisporus by the removal of volatile $\mathrm{C} 8$ compounds $[75,76]$. The relative abundance of these beneficial bacteria on blotched caps is yet to be explored, 
in relation to disease expression by blotch causing bacteria. Brevundimonas isolate, P7753 (phylotype 30), closely related to $B$. bullata was also discovered on symptomatic cap tissue. During the cultivation cycle, increased Brevundimonas populations have been observed in the casing soils from $A$. bisporus and $P$. ostreatus farms [58, 77, 78], and Brevundimonas sp. can be thus expected to also colonize mushroom caps. It has also been reported as a symbiont on the apothecia of the cup fungus, Scutellinia scutellata [79].

\section{Conclusion}

This study provides a detailed overview of the regional, genetic and phenotypic diversity of bacterial blotch pathogens in Western Europe. It describes the presence of known pathogens inhabiting blotched mushroom caps: "P. gingeri", P. tolaasii, P. costantinii and "P. reactans". It also reports seven new pathogens of bacterial blotch: four Pseudomonas species, P. yamanorum, $P$. edaphica, P. salomonii and strains belonging to the same species as Pseudomonas sp. NC02, and three non-pseudomonads, S. liquefaciens, S. proteamaculans and a Pantoea sp. Their epidemiology and aetiology deserve further attention. This molecular investigation of bacterial species that colonize blotched mushroom caps allows further study of the mechanisms and microbial ecology of symptomatic disease expression on the A. bisporus sporophore. It also highlights the need for development of diagnostic assays against these newly discovered pathogens. Several new blotch-causing phylotypes discovered in this study are as yet unidentified and require additional chemotaxic data for their taxonomic assignment as new species.

\section{Supplementary information}

Supplementary information accompanies this paper at https://doi.org/10. 1186/s12864-020-06905-3.

Additional file 1. Isolates and reference strains that were sequenced, with metadata on initial identity, pathogenicity, source, region of outbreak, year of outbreak, MLSA, ANI and dDDH.

Additional file 2 Barcoding genes and genome duplication in Pseudomonas isolates that map in specifically and remain unidentified. It describes the number of copies of nine barcoding genes found in the assembled genome, and the overall percentage of genome duplication in the assembly.

\section{Acknowledgements}

We would like to thank P Kastelein, B Brankovics, J Baars, H Pufal, B Carter, A Dobrovin-Pennington and J Vicente for their support.

\section{Authors' contributions}

TT and MK sampled and processed the diseased mushrooms; TT performed the pathogenicity assays. TT, MK and EH performed the molecular characterization. $\Pi \mathrm{T}, \mathrm{MK}, \mathrm{EH}, \mathrm{JE}, \mathrm{RN}$ and JW analysed the results. TT wrote the first draft of the manuscript; JE, RN and JW critically reviewed the draft. All authors contributed to subsequent manuscript revision, read and approved the submitted version.

\section{Funding}

The project in Netherlands was granted by the Topsector 'Horticulture and propagation material' of the Dutch Ministry of Economic Affairs. It was conducted under grant number KV1509-050 in collaboration with members of the Dutch and Belgian mushroom supply chain. Work in the United Kingdom was funded by the Agriculture and Horticulture Development Board under project number M063. The funders had no role in research design, data generation, analysis, and preparation of the manuscript.

\section{Availability of data and materials}

The datasets generated and/or analysed during the current study are available in the NCBI repository under BioProject number PRJNA607442.

Ethics approval and consent to participate

Not applicable.

Consent for publication

Not applicable.

\section{Competing interests}

The authors declare that they have no competing interests.

\section{Author details}

${ }^{1}$ Biointeractions and Plant Health, Wageningen University and Research, Wageningen, Netherlands. ${ }^{2}$ Department of Microbial Ecology, Netherlands Institute of Ecology, Wageningen, Netherlands. ${ }^{3}$ Department of Plant Protection, Fera Science Limited, York, UK. ${ }^{4}$ Pershore College, Warwickshire College Group, Worcestershire, UK.

Received: 31 March 2020 Accepted: 10 July 2020

Published online: 22 July 2020

\section{References}

1. Hayes WA, Randle PE, Last FT. The nature of the microbial stimulus affecting sporophore formation in Agaricus bisporus (Lange) sing. Ann Appl Biol. 1969; 64(1):177-87.

2. Eger $G$. The" Halbschalentest"-a simple method for testing-casing materials. MGA Bull Grow Assoc. 1962;148:159-68.

3. Thomas DS, Mullins JT, Block SS. Involvement of volatiles in mushroom sporophore initiation. Mushroom Grow Assoc Bull. 1964;177:429-33.

4. Preece TF, Wong WC. Quantitative and scanning electron microscope observations on the attachment of Pseudomonas tolaasii and other bacteria to the surface of Agaricus bisporus. Physiol Plant Pathol. 1982;21(2):251-7.

5. Wong WC, Preece TF. Pseudomonas tolaasii in mushroom crops: a note on primary and secondary sources of the bacterium on a commercial farm in England. J Appl Bacteriol. 1980;49(2):305-14.

6. Fletcher JT, White PF, Gaze RH. Mushrooms: pest and disease control 2nd edition. Andover: UK Intercept; 1989. p. 174.

7. Fletcher JT, Gaze RH. Mushroom pest and disease control: a colour handbook: CRC Press; 2007.

8. Gomila M, Peña A, Mulet M, Lalucat J, García-Valdés E. Phylogenomics and systematics in Pseudomonas. Front Microbiol. 2015;6:214.

9. Godfrey SAC. Molecular investigation of pseudomonads causative of Agaricus bisporus blotch disease in New Zealand mushroom farms; 2003.

10. Hume DP, Hayes WA. The production of fruit-body primordia in Agaricus bisporus (Lange) sing. On agar media. Mushroom Sci. 1972;7:527-32.

11. Tolaas AG. A bacterial disease of cultivated mushrooms. Phytopathology. 1915;5(1):U51-5

12. Paine SG. A brown blotch disease of cultivated mushrooms. Ann Appl Biol. 1919;5:206-19.

13. Brennan M, Le Port G, Gormley R. Post-harvest treatment with citric acid or hydrogen peroxide to extend the shelf life of fresh sliced mushrooms. LWTFood Sci Technol. 2000;33(4):285-9.

14. Burton KS. The effects of pre-and post-harvest development on mushroom tyrosinase. J Hortic Sci. 1988;63(2):255-60.

15. Burton KS, Noble R. The influence of flush number, bruising and storage temperature on mushroom quality. Postharvest Biol Technol. 1993:3(1):39-47.

16. Soler-Rivas C, Jolivet S, Arpin N, Olivier JM, Wichers HJ. Biochemical and physiological aspects of brown blotch disease of Agaricus bisporus. FEMS Microbiol Rev. 1999;23(5):591-614. 
17. Wells JM, Sapers GM, Fett WF, Butterfield JE, Jones JB, Bouzar H, et al. Postharvest discoloration of the cultivated mushroom Agaricus bisporus caused by Pseudomonas tolaasii, P.'reactans', and P.'gingeri'. Phytopathology. 1996;86(10):1098-104.

18. Wong WC, Fletcher JT, Unsworth BA, Preece TF. A note on ginger blotch, a new bacterial disease of the cultivated mushroom, Agaricus bisporus. J Appl Bacteriol. 1982;52(1):43-8.

19. Young JM. Drippy gill: a bacterial disease of cultivated mushrooms caused by Pseudomonas agarici n. sp. New Zeal J Agric Res. 1970;13(4):977-90.

20. Abou-Zeid MA. Pathogenic variation in isolates of Pseudomonas causing the brown blotch of cultivated mushroom, Agaricus bisporus. Brazilian J Microbiol. 2012;43(3):1137-46.

21. Nair NG, Bradley JK. Mushroom blotch bacterium during cultivation. Mushroom J. 1980;90:201-3.

22. Elphinstone J, Noble R. Mushrooms: Identification, detection and control of different Pseudomonas species causing bacterial blotch symptoms. Kenilworth: UK Agriculture and Horticulture Development Board (AHDB) Horticulture, Report M063; 2018.

23. Osdaghi E, Martins S, Ramos-Sepulveda L, Vieira FR, Pecchia J, Beyer DM, et al. 100 Years since Tolaas: Bacterial Blotch of Mushrooms in the 21st Century. Plant Dis. 2019;103(11):2714-32.

24. Munsch P, Alatossava T. The white-line-in-agar test is not specific for the two cultivated mushroom associated pseudomonads, Pseudomonas tolaasii and Pseudomonas "reactans". Microbiol Res. 2002;157(1):7-11.

25. van der Wolf JM, Kastelein P, Krijger MC, Hendriks MJA, Baars JJP, Amsing JGM, et al. Characterization of Pseudomonas species causing brown blotch of Agaricus bisporus. Int Soc Mushroom Sci. 2016;19:104-8.

26. Godfrey SAC, Marshall JW, Klena JD. Genetic characterization of Pseudomonas 'NZI7'-a novel pathogen that results in a brown blotch disease of Agaricus bisporus. J Appl Microbiol. 2001;91(3):412-20.

27. Godfrey SAC, Harrow SA, Marshall JW, Klena JD. Characterization by 165 rRNA sequence analysis of pseudomonads causing blotch disease of cultivated Agaricus bisporus. Appl Environ Microbiol. 2001;67(9):4316-23.

28. Marino PL, Sutin KM, del Sol Jaquotot MJ. El Libro de la UCI 3rd Edition; 2008

29. King EO, Ward MK, Raney DE. Two simple media for the demonstration of pyocyanin and fluorescin. J Lab Clin Med. 1954;44(2):301-7 Available from: https://www.translationalres.com/article/0022-2143(54)90222-X/abstract.

30. Zeigler DR. Gene sequences useful for predicting relatedness of whole genomes in bacteria. Int J Syst Evol Microbiol. 2003;53(6):1893-900.

31. Adékambi T, Butler RW, Hanrahan F, Delcher AL, Drancourt M, Shinnick TM. Core gene set as the basis of multilocus sequence analysis of the subclass Actinobacteridae. PLoS One. 2011;6(3):e14792.

32. Tamura K, Nei M, Kumar S. Prospects for inferring very large phylogenies by using the neighbor-joining method. Proc Natl Acad Sci. 2004;101(30):11030-5.

33. Team RC. R: A language and environment for statistical computing; 2013.

34. Yu G, Smith DK, Zhu H, Guan Y, Lam TT. ggtree: an R package for visualization and annotation of phylogenetic trees with their covariates and other associated data. Methods Ecol Evol. 2017;8(1):28-36.

35. Goris J, Konstantinidis KT, Klappenbach JA, Coenye T, Vandamme P, Tiedje JM. DNA-DNA hybridization values and their relationship to whole-genome sequence similarities. Int J Syst Evol Microbiol. 2007;57(1):81-91.

36. Richter M, Rosselló-Móra R. Shifting the genomic gold standard for the prokaryotic species definition. Proc Natl Acad Sci. 2009;106(45):19126-31.

37. Pritchard L, Cock P, Esen Ö. pyani v0. 2.8: average nucleotide identity (ANI) and related measures for whole genome comparisons; 2019.

38. Auch AF, von Jan M, Klenk H-P, Göker M. Digital DNA-DNA hybridization for microbial species delineation by means of genome-to-genome sequence comparison. Stand Genomic Sci. 2010;2(1):117.

39. Meier-Kolthoff JP, Auch AF, Klenk H-P, Göker M. Genome sequence-based species delimitation with confidence intervals and improved distance functions. BMC Bioinformatics. 2013;14(1):60.

40. Meier-Kolthoff JP, Göker M. TYGS is an automated high-throughput platform for state-of-the-art genome-based taxonomy. Nat Commun. 2019;10(1):2182.

41. Lefort V, Desper R, Gascuel O. FastME 2.0: a comprehensive, accurate, and fast distance-based phylogeny inference program. Mol Biol Evol. 2015;32: 2798-800. https://doi.org/10.1093/molbev/msv150.

42. Glaeser SP, Kämpfer P. Multilocus sequence analysis (MLSA) in prokaryotic taxonomy. Syst Appl Microbiol. 2015;38(4):237-45.

43. Arnau VG, Sánchez LA, Delgado OD. Pseudomonas yamanorum sp. nov., a psychrotolerant bacterium isolated from a subantarctic environment. Int J Syst Evol Microbiol. 2015;65(2):424-31.
44. Basim E, Basim H. Characterization of Pseudomonas tolaasii isolates, causing Brown blotch disease of mushroom (Agaricus bisporus). Int J Agric Biol. 2018;20(12):2721-30.

45. Holland BR, Huber KT, Dress A, Moulton V. $\delta$ plots: a tool for analyzing phylogenetic distance data. Mol Biol Evol. 2002;19(12):2051-9.

46. Cerra J, Donohue H, Kral A, Oser M, Rostkowski L, Zappia L, et al. Complete genome sequence of Pseudomonas sp. strain NCO2, isolated from soil. Genome Announc. 2018;6(7):e00033-18.

47. Ramírez-Bahena MH, Salazar S, Santín PJ, Sánchez-Rodríguez JA, FernándezPascual M, Igual JM, et al. Pseudomonas edaphica sp. nov., isolated from rhizospheric soil of Cistus ladanifer L. in Spain. Int J Syst Evol Microbiol. 2019; 69(10):3141-7.

48. Gardan L, Bella P, Meyer J-M, Christen R, Rott P, Achouak W, et al. Pseudomonas salomonii sp. nov., pathogenic on garlic, and Pseudomonas palleroniana sp. nov., isolated from rice. Int J Syst Evol Microbiol. 2002;52(6): 2065-74.

49. Caldera L, Franzetti LV, Van Coillie E, De Vos P, Stragier P, De Block J, et al. Identification, enzymatic spoilage characterization and proteolytic activity quantification of Pseudomonas spp. isolated from different foods. Food Microbiol. 2016;54:142-53.

50. lacobellis NS, Cantore PL. Pseudomonas "reactans" a new pathogen of cultivated mushrooms. In: Pseudomonas syringae and related pathogens. Dordrecht: Springer; 2003. p. 595-605.

51. Kämpfer $P$, Glaeser SP. Prokaryotic taxonomy in the sequencing era-the polyphasic approach revisited. Environ Microbiol. 2012;14(2):291-317.

52. Fulton MM. A simple lab exercise demonstrating Koch's postulates. Am Biol Teach. 1981:43(7):394-6.

53. Doores S, Kramer M, Beelman R. Evaluation and bacterial populations associated with fresh mushrooms (AgaricusBisporus). In: Developments in crop science: Elsevier; 1987. p. 283-94.

54. Cutri SS, Macauley BJ, Roberts WP. Characteristics of pathogenic nonfluorescent (smooth) and non-pathogenic fluorescent (rough) forms of Pseudomonas tolaasii and Pseudomonas gingeri. J Appl Bacteriol. 1984;57(2): 291-8.

55. Garrido-Sanz D, Meier-Kolthoff JP, Göker M, Martin M, Rivilla R, RedondoNieto M. Genomic and genetic diversity within the Pseudomonas fluorescens complex. PLoS One. 2016;11(2):e0150183.

56. Loper JE, Hassan KA, Mavrodi DV, Davis EW II, Lim CK, Shaffer BT, et al. Comparative genomics of plant-associated Pseudomonas spp.: insights into diversity and inheritance of traits involved in multitrophic interactions. PLoS Genet. 2012;8(7):e1002784.

57. Munsch P, Alatossava T, Marttinen N, Meyer J-M, Christen R, Gardan L. Pseudomonas costantinii sp. nov., another causal agent of brown blotch disease, isolated from cultivated mushroom sporophores in Finland. Int J Syst Evol Microbiol. 2002;52(6):1973-83.

58. Mcgee CF, Byrne H, Irvine A, Wilson J. Diversity and dynamics of the DNA and CDNA-derived bacterial compost communities throughout the Agaricus bisporus mushroom cropping process. Ann Microbiol. 2017;67(11):751-61.

59. Jarial RS, Shandilya TR, Jarial K. Casing in mushroom beds-a review. Agric Rev Res Commun Cent INDIA. 2005;26(4):261.

60. Reyes JE, Venturini ME, Oria R, Blanco D. Prevalence of Ewingella americana in retail fresh cultivated mushrooms (Agaricus bisporus, Lentinula edodes and Pleurotus ostreatus) in Zaragoza (Spain). FEMS Microbiol Ecol. 2004;47(3):291-6.

61. Sivanesan D. Diversity among bacteria causing blotch disease on the commercial mushroom, Agaricus bisporus; 2003.

62. Grewal PS. Influence of bacteria and temperature on the reproduction of Caenorhabditis elegans (Nematoda: Rhabditidae) infesting mushrooms (Agaricus bisporus). Nematologica. 1991;37(1-4):72-82.

63. Watanabe T, Kimura K, Sumiya T, Nikaidou N, Suzuki K, Suzuki M, et al. Genetic analysis of the chitinase system of Serratia marcescens 2170. J Bacteriol. 1997;179(22):7111-7.

64. Matsuyama T, Kaneda K, Nakagawa Y, Isa K, Hara-Hotta H, Yano I. A novel extracellular cyclic lipopeptide which promotes flagellum-dependent andindependent spreading growth of Serratia marcescens. J Bacteriol. 1992; 174(6):1769-76.

65. Matsuyama T, Murakami T, Fujita M, Fujita S, Yano I. Extracellular vesicle formation and biosurfactant production by Serratia marcescens. Microbiology. 1986;132(4):865-75.

66. Hildebrand PD. Surfactant-like characteristics and identity of bacteria associated with broccoli head rot in Atlantic Canada. Can J Plant Pathol. 1989;11(3):205-14 
67. Brenner DJ, Family I. Enterobacteriaceae. Bergey's Man Syst Bacteriol. 1984;1: 408-516.

68. Holt JG, Krieg NR, Sneath PHA. Bergey's manual of determinative bacterology; 1994

69. Kim MK, Ryu JS, Lee YH, Yun HD. First report of Pantoea sp. induced soft rot disease of Pleurotus eryngii in Korea. Plant Dis. 2007;91(1):109.

70. Walpola BC, Noh J-G, Kim CK, Kyung K-C, Kong W-S, Yoon M-H. Optimization of indole-3-acetic production by phosphate solubilization bacteria isolated from waste mushroom bed of Agaricus bisporus. 2013;11(2):53-62.

71. Jhune C-S, Yun H-S, Park Y-J, Weon H-Y, Yoo Y-B, Lee C-J, et al. Studies on the outbreak cause of inner tissue browning and malformed symptoms on fruiting body of Agaricus brazilensis. J Mushroom. 2009;7(4):168-72.

72. Rossouw W, Korsten L. Cultivable microbiome of fresh white button mushrooms. Lett Appl Microbiol. 2017:64(2):164-70.

73. Yan JJ, Chen BZ, Wang RQ, Liu F, Wei Q, Xie BG, et al. First report of Cedecea neteri-induced soft rot disease of Pholiota nameko in China. Plant Dis. 2018; 102(10):2025.

74. Yan JJ, Liu YY, Wang RQ, Mukhtar I, Liu F, Lin ZY, et al. First report of Cedecea neteri causing yellow sticky disease in Flammulina velutipes in China. Plant Dis. 2019;103(5):1014.

75. Fermor T, Lincoln S, Noble R, Dobrovin-Pennington A, Colauto N. Microbiological properties of casing. Mushroom Sci. 2000;15(1):447-54.

76. Noble R, Dobrovin-Pennington A, Hobbs PJ, Pederby J, Rodger A. Volatile C8 compounds and pseudomonads influence primordium formation of Agaricus bisporus. Mycologia. 2009;101(5):583-91.

77. Nazareth SA, Surridge-Talbot AKJ, Korsten L. Bacterial profiling of casing materials for white button mushrooms (Agaricus bisporus) using denaturing gradient gel electrophoresis; 2010.

78. Cho YS, Weon HY, Joh JH, Lim JH, Kim KY, Son ES, et al. Effect of casing layer on growth promotion of the edible mushroom Pleurotus ostreatus. Mycobiology. 2008;36(1):40-4.

79. Giordano R, Nardi JB, Bee CM, Miller LA, Raja H. Bacterial symbionts that inhabit apothecia of the cup fungus Scutellinia scutellata. Nov Hedwigia. 2013;97(1-2):1-18.

\section{Publisher's Note}

Springer Nature remains neutral with regard to jurisdictional claims in published maps and institutional affiliations.

Ready to submit your research? Choose BMC and benefit from:

- fast, convenient online submission

- thorough peer review by experienced researchers in your field

- rapid publication on acceptance

- support for research data, including large and complex data types

- gold Open Access which fosters wider collaboration and increased citations

- maximum visibility for your research: over $100 \mathrm{M}$ website views per year

At $\mathrm{BMC}$, research is always in progress.

Learn more biomedcentral.com/submissions 